[Transaction ]

\title{
Fashion Leadership, Market Mavenism, and Store Evaluative Criteria
}

\author{
Hye-Shin Kim $\cdot$ Eunah Yoh* ${ }^{\dagger}$ \\ Dept. of Fashion \& Apparel Studies, University of Delaware \\ *Dept. of Fashion Marketing, Keimyung University \\ Received March 26, 2009; Revised April 28, 2009; Accepted May 11, 2009 \\ 패션선도력, 시장전문성, 점포평가기준에 관한 연구 \\ 김혜신 · 여은아* ${ }^{\dagger}$ \\ Dept. of Fashion \& Apparel Studies, University of Delaware, *계명대학교 패션마케팅학과 \\ 접수일(2009년 3월 26일), 수정일(2009년 4월 28일), 게재확정일(2009년 5월 11일)
}

\begin{abstract}
This study compares fashion leaders and market mavens by examining the demographic characteristics of fashion leaders and market mavens and how they differ in their evaluation of store and shopping related attributes. Data originated from a national consumer mail survey in the United States. The survey included items measuring market mavenism, fashion leadership, store evaluative attributes, and personal information. Responses from 380 consumers were used for data analysis. Female consumers were found to be more active in word-of-mouth activities in general. Young consumers were more inclined to express fashion leadership while age was not related to market mavenism. A lower level of education increased tendencies for both market mavenism and fashion leadership. In terms of store evaluative criteria, the majority of items in the survey were more important as fashion leadership and market mavenism tendencies increased. Interestingly, the need for knowledgeable or helpful salespeople did not increase with fashion leadership tendencies. Also, fashion leaders were interested in easy return of merchandise and were likely to spend more time in the stores. This study sheds important light on how fashion leadership differ compared to market mavenism. By simultaneously examining fashion leadership and market mavenism using a strong sample base, this study provides sound evidence of how consumers interested in fashion may have differing needs for shopping.
\end{abstract}

Key Words: Fashion leadership, Market mavenism, Store evaluative criteria; 패션선도력, 시장전문성, 점포평가기준

\section{Introduction}

With growing competition for consumer attention and increasing complexity of marketplace information, interpersonal communication has been increasingly highlighted as a powerful information source where word-of-mouth agents provide shortcuts for

Corresponding author

E-mail: yoheunah@kmu.ac.kr consumers to navigate through the plethora of resources and information. As consumers look to other consumers with non profit-oriented motives for guidance in their buying decisions, adding further credibility to their passion as a consumer, interpersonal communication continues to be important to marketers and consumers alike.

The concept of fashion is defined as a form of collective behavior that is socially accepted at a given 
time (Kaiser, 1985). Due to this fact, fashion has long been recognized as a consumption activity in which the consumer behavior of a critical group of consumers, referred as to as fashion leaders or fashion innovators, is vital to its success and profitability. This leading group of consumers plays an important role in bringing to attention innovative and creative product styles to the rest of the consumer market. The fashion industry, representing a range of product categories from apparel to accessories, is very much dependent on word-of-mouth communication where the buying decisions of consumers becomes a critical marketing tool which adds acceptance and visibility to product offerings for other consumers and also provides indication for future product planning purposes for companies. In the general marketing and consumer literature, the term market mavenism has been widely studied in relation to word-of-mouth communication. Market mavens are consumers who influence the marketplace by providing general shopping and marketplace information (Feick \& Price, 1987). Market mavens are influential in other consumers' decision-making by providing a supportive role as information providers and advisors. The similarities of fashion leaders and market mavens lie in that they are both considered innovative consumers and opinion leaders.

As recognized agents of word-of-mouth communication in marketing and fashion-related fields, this study conducts a comparison study of fashion leaders and market mavens by examining (1) the demographic characteristics of fashion leaders and market mavens and (2) how they differ in their evaluation of store and shopping related attributes, that is store evaluative criteria. First, this study examines and compares the personal characteristics of market mavens and fashion leaders. Next, an important factor that influences consumer decision making, how consumers perceive and value store attributes, is studied to better understand how fashion leaders may differ from market mavens. Because fashion leadership is defined within a particular product category, this study seeks to better understand how fashion consumers may differ in their shopping behaviors and preferences compared to other shoppers in general providing further evidence of the uniqueness of fashion in terms of marketing, retailing, and consumer shopping.

\section{Literature Review}

\section{Fashion Leadership and Market Mavenism}

Fashion leaders (also referred to as fashion opinion leaders) are individuals who serve as a source of information and influential in the decision making of other individuals on whether to adopt fashion-related products (Rogers, 1983; Summers, 1970). Fashion products possess symbolic features in which shared social meaning is important. The importance people attach to specific consumption goods, such as those that are fashion-related, is very much evidenced in how these products receive social approval and becomes adopted and accepted by a collective group. As such, personto-person interaction and exchange of information is a key to the acceptance and adoption of fashion. And thus, fashion leaders are considered important agents that stimulate the diffusion of a wide array of consumer products. Through the years, consumer interest in fashion has been conceptualized and studied using various similar and strongly related constructs such as fashion leadership, fashion opinion leadership (Huddleston et al., 1993), fashion involvement (Fairhurst et al., 1989), and fashion perceptions (Summers et al., 1992).

The market mavenism construct stems from the conceptualization originally presented in Feick and Price's (1987) original study. Market mavens were first identified by Feick and Price (1987) as general marketplace influencers whose tendency to be informative was visible across a broad range of consumer goods. According to Feick and Price (1987), market mavens are defined as "Individuals who have information about many kind of products, places to shop and other facets of markets, and initiate discussion with consumers and respond to requests from consumers for marketplace information (Feick \& Price, 1987)".

Although market mavens are similar to other consumers who show a high level of interests in certain products, are active information seekers, and are highly involved consumers, market mavenism has 
been found to be a separate and distinct concept. For example, Feick and Price (1987) found that compared to the innovative consumer, market mavens tend to be more innovative across a broad range of consumer goods. Wiedmann et al. (2001) confirm that market mavens have a good overall market-related knowledge and a willingness to disseminate information that is not product specific. Market mavens use their knowledge and transmit information to satisfy a social and entertainment purpose (Price et al., 1987).

\section{Demographic Characteristics}

Demographic characteristics are known to influence consumer behavior. While findings concerning how demographic characteristics may be used to profile fashion leaders and market mavens have varied, some consistent findings are evidenced. First, interest in fashion or fashion leadership has been associated with younger consumers (Goldsmith et al., 1987; Gutman \& Mills, 1982; Summers, 1970; Summers et al., 1992; Tatzel, 1982). Also, as females are recognized as primary purchasers of apparel, studies identify female consumers to be more interested in fashion (Summers, 1970; Summers et al., 1992; Tatzel, 1982). Other findings pertaining to the demographic characteristics of fashion consumers are published but less consistent evidence is found. In terms of income, many studies have found fashion leaders to have higher socio economic status (Rogers, 1983) and higher occupational status (Polegato \& Wall, 1980). Income has also been associated with fashion leaders by many researchers (Hirschman, 1979; Huddleston et al., 1993; Summers, 1970; Summers et al., 1992).

On the other hand, Tatzel (1982) found clothes conscious consumer to be at the lower income level and Goldsmith et al. (1991) found no relationship with income. Educational level has also been cited to be predictive of fashion leadership by many researchers (Huddleston et al., 1993; Polegato \& Wall, 1980; Summers et al., 1992), whereas Goldsmith et al. (1991) found no relationship between fashion leadership and education. Although many studies have examined the demographic characteristics of fashion consumers, most of these studies have been published in the 1980s and early 1990s and do not reflect the current consumer population. Also, although results contribute to the knowledge base of fashion consumers, many studies used data from limited convenience samples (e.g., female University students) and thus generalization of the findings to a larger population base is limited.

The demographic characteristics of market mavens are less clear with scholars presenting less consistent results. For example, studies by some studies report market mavens to be more likely female (Feick \& Price, 1987; Higie et al., 1987; Williams \& Slama, 1995), whereas other studies report the male gender (Abratt et al., 1995; Walsh et al., 2004). Also, a few studies suggest market mavens to be younger (Walsh et al., 2004; Wiedmann et al., 2001; Williams \& Slama, 1995) and less educated (Feick \& Price, 1987; Williams \& Slama, 1995). Fewer studies have been conducted on demographic characteristics in regards to market mavenism. Although, some similarities between fashion leaders and market mavens can be derived by comparing various studies, it is hard to draw a strong conclusion based on the studies. Hence, this study examines the following research question:

Research Question 1: What are the relationships of demographic characteristics (in terms of gender, age, education, and income) with fashion leadership versus market mavenism?

\section{Store Evaluative Criteria and Shopping Be- havior}

Fashion leaders and market mavens share common ground in that they are motivated to shop and considered by others as major sources of information that influence consumer decision making. For example, Summers et al. (1992) found evidence that time spent shopping on self was related to fashion commitment and importance of clothing image and Goldsmith et al. (1991) found fashion leaders spent more money on clothing. Market mavens have been found to enjoy shopping (Feick \& Price, 1987) and consider shopping as recreational (Walsh \& Mitchell, 2001; Wiedmann et al., 2001). As major marketplace influencers, 
fashion leaders and market mavens are important target markets because of their ability to influence the decision-making of other consumers. Because of their tendencies to transmit information, they are more likely to talk about product and store attributes such as sales, prices, quality, merchandise offerings, and customer service (Abratt et al., 1995; Feick \& Price, 1987; Higie et al., 1987; Lichtenstein \& Burton, 1990; Slama \& Williams, 1990).

As part of the buyer decision process, consumers use criteria to evaluate purchase alternatives. The evaluative criteria are mostly based on the attributes and benefits buyers seek from products and stores in the consideration set (Williams \& Slama, 1995). Past research has suggested that a wide range of evaluative criteria could be applied depending on such factors as the purchase situation (Dickson, 1982), purchase experience (Bettman \& Sujan, 1987), and personal variables (Williams, 2002). Williams and Slama (1995) provide evidence that some general attributes that pertain to products and retail stores are relevant to a wide range of purchase decisions. Product and store evaluative criteria such as quality, image, convenience, and functionality are generally applicable to a wide range of products and stores.

Past research on fashion leaders and market maven respectively show some distinct preferences in their buying behaviors compared to other consumers. For example, early research found fashion conscious consumers to shop in traditional department stores or specialty stores (Gutman \& Mills, 1982; Hirschman, 1979). A study by Fairhurst et al. (1989) confirm that various measures of fashion involvement are positively related to store attributes such as merchandise assortment and quality, brand names, store services, and up-to-date merchandise. Also, consumers with more innovative tendencies for men's fashion apparel expressed more concern for guarantee, exchange, and adjustment policies. In studies concerning market mavens, studies by Walsh and Mitchell (2001) and Wiedmann et al. (2001) found market mavens to be price conscious. Williams and Slama (1995) found market mavens to differ in how they attached importance to evaluative criteria. In addition, Williams and Slama (1995) also found female mavens had greater concern for store selection criteria with emphasis on value and service.

In a retail shopping environment, it is almost impossible to visit all stores that carry similar products. Consumers must carefully select from a wide number of retail stores. Store attributes are of significant importance to consumers when deciding whether to spend time shopping in particular stores. Store evaluative criteria provide valuable insight into how consumers form positive impressions of a particular store as well as their buying behavior. Because evaluative criteria are considered to be influential in consumer decision-making, examining the store evaluative criteria of market mavens and fashion leaders provides a comparative understanding of consumers who are influential word-of-mouth agents for general marketplace information (market mavens) and consumers who are influential in regards to fashion. The following research question provides insight into how fashion leaders differ in terms of importance of store evaluative criteria compared to market mavens.

Research Question 2: What is the relationship of store evaluative criteria with fashion leadership and market mavenism and how do store evaluative criteria differ between fashion leaders and market mavens?

\section{Methods}

\section{Data Collection Methods and Respondent Characteristics}

Data used in this study originated from a national consumer survey of U.S. inner city and non inner city consumers. Which was funded by the International Council of Shopping Centers Educational Foundation (ICSCEF). The national consumer survey was conducted using a randomly generated consumer mailing list purchased from a data marketing company. The data marketing company generated the mailing list from Acxiom's InfoBase database, which integrates information from over fifteen of the nation's top data sources, and is verified and cleaned. For the purpose of this particular study, data from consumers living in non-inner city areas were used 
because it represented a much larger and diverse population and broader coverage of areas in the United States. Inclusion of data from inner city consumers would have resulted in a disproportionate number of consumers from this group and a biased coverage of geographic areas. In terms of the consumer sample used for this study, data were collected using the randomly generated mailing list of 4,993 consumers living in non inner city areas. First mail pieces including the survey were mailed and reminder postcards were mailed two weeks later. From the original mailings, 411 were returned with no forwarding address and returned questionnaires from 380 consumers were considered usable for data analysis.

<Table 1> summarizes the demographic characteristics of the sample. A high majority of the respondents were females (71.8\%) and of Caucasian (90.2\%) racial/ethnic group. The sample was well distributed

Table 1. Sample characteristics

\begin{tabular}{|c|c|c|c|}
\hline Characteristic & & $\mathrm{N}$ & $\%$ \\
\hline \multirow{2}{*}{ Gender } & Male & 107 & 28.2 \\
\hline & Female & 273 & 71.8 \\
\hline \multirow{6}{*}{ Age } & $18-25 \mathrm{yrs}$ & 21 & 5.6 \\
\hline & $26-35$ yrs & 39 & 10.2 \\
\hline & $36-45$ yrs & 60 & 15.8 \\
\hline & $46-55 \mathrm{yrs}$ & 101 & 26.5 \\
\hline & $56-65$ yrs & 89 & 23.3 \\
\hline & Over 65 yrs & 71 & 18.7 \\
\hline \multirow{5}{*}{ National or ethnic group } & Caucasian & 343 & 90.2 \\
\hline & African American & 11 & 2.9 \\
\hline & Hispanic & 12 & 3.2 \\
\hline & Asian & 4 & 1.1 \\
\hline & Other & 10 & 2.7 \\
\hline \multirow{5}{*}{ Education } & Not a high school graduate & 11 & 2.9 \\
\hline & High school graduate & 161 & 42.3 \\
\hline & Associate's degree & 32 & 8.5 \\
\hline & College degree & 111 & 29.1 \\
\hline & Graduate degree & 65 & 17.2 \\
\hline \multirow{10}{*}{ Income } & Under $\$ 15,000$ & 31 & 8.1 \\
\hline & $\$ 15,000$ to $\$ 24,999$ & 34 & 8.9 \\
\hline & $\$ 25,000$ to $\$ 34,999$ & 51 & 13.4 \\
\hline & $\$ 35,000$ to $\$ 49,999$ & 75 & 20.1 \\
\hline & $\$ 50,000$ to $\$ 74,999$ & 79 & 20.9 \\
\hline & $\$ 75,000$ to $\$ 99,999$ & 47 & 12.3 \\
\hline & $\$ 100,000$ to $\$ 124,999$ & 31 & 8.1 \\
\hline & $\$ 125,000$ to $\$ 149,999$ & 10 & 2.5 \\
\hline & $\$ 150,000$ to $\$ 199,999$ & 12 & 3.1 \\
\hline & $\$ 200,000$ or more & 11 & 2.8 \\
\hline \multirow{7}{*}{ Occupation } & Management, professional, and related occupations & 154 & 40.5 \\
\hline & Service occupations & 38 & 9.9 \\
\hline & Sales and office occupations & 39 & 10.2 \\
\hline & Farming, fishing, and forestry occupations & 6 & 1.7 \\
\hline & Construction, extraction, and maintenance occupations & 14 & 3.8 \\
\hline & Production, transportation, and material moving occupations & 13 & 3.5 \\
\hline & Other & 115 & 30.3 \\
\hline
\end{tabular}


across age groups with consumers 46-55 and 56-65 years age ranges each representing a quarter of the sample. A high majority of the sample had a minimum of a high school degree and 46 percent of the sample had a college or graduate degree. Income levels were also well distributed across consumer groups with half of the sample indicating their household income between $\$ 35,000$ and $\$ 74,999$. Finally, 40 percent of the respondents indicated their occupations to be in the category of management, professional, and related occupations.

\section{Measures}

With the exclusion of items measuring personal variables, all items were measured on a 5-point Likert type scale (1-strongly disagree, $5=$ strongly agree). For market mavenism, the original six-item market maven scale developed by Feick and Price (1987) was used in the study. The scale measures consumer tendencies to provide general shopping and marketplace information to consumers. A sample item of the market maven scale is "I like helping people by providing them with information about many kinds of products". For fashion leadership, a five-item scale was developed by the researchers based on scales used by Hirschman and Adcock (1977). A sample item of the fashion leadership scale is "I influence the type of clothing my friends buy". Responses for both market mavensim and fashion leadership were combined and a composite score was generated for each respondent with high scores indicated a greater tendency towards market mavenism and fashion leadership respectively. The market mavenism scale showed a Cronbach's alpha (Nunnally, 1978) of 0.90 and fashion leadership was 0.88 .

To identify market mavens and fashion leaders, the sample was divided into thirds following methods of previous studies for market mavenism (e.g., Feick \& Price, 1987; Walsh et al., 2004; Williams \& Slama, 1995). Using the trichotomization method, respondents were categorized into low, medium, and high groups based on their mean scores across the six items measuring market mavenism. Given the distribution of the scores, the three groups were not exactly the same but a best attempt was made to divide the groups into equal sizes. Respondents "high" in their market mavenism scores are referred to as market mavens ( $n_{\text {high group }}=149$, mean $=3.93$ ), and "medium" in market mavenism are referred to as moderate market mavens ( $n_{\text {medium group }}=108$, mean $=3.13$ ), and "low" in market mavenism are referred to as nonmarket mavens ( $n_{\text {low group }}=123$, mean $\left.=1.95\right)$. To allow for comparison of data between market mavens and fashion leaders, the trichotomization method used to identify market mavens was also used to identify fashion leaders. For fashion leadership, respondents "high" in their fashion leadership scores are referred to as fashion leaders $\left(n_{\text {high group }}=155\right.$, mean $\left.=3.42\right)$, and "medium" in fashion leadership are referred to as moderate fashion leaders $\left(n_{\text {medium group }}=118\right.$, mean $=2.29$ ), and "low" in fashion leadership are referred to as nonfashion leaders ( $n_{\text {low group }}=107$, mean $\left.=1.41\right)$. Analysis of variance and post hoc multi-group tests verified significant differences among groups for both market mavenism ( $d f=2$, Mean Square $=132.19, F=782.71$, Sig. $=.000)$ and fashion leadership ( $d f=2$, Mean Square $=$ 131.56, $F=809.29$, Sig.=.000).

Items measuring store evaluative criteria were partially adopted from items in a study by Williams and Slama (1995). The items measure various aspects of the store and products offered in the store such as product quality and value, assortment offerings, store and product prestige and likeability, and customer service and accessibility. The items were assessed with 5-point scales (1=Not Important, 2=Rarely Important, 3=Somewhat Important, 4=Important, 5=Most Important). The items were not intended to be exhaustive but were selected for their general applicability to a wide range of products and stores (Williams \& Slama, 1995). Because each item measured a unique aspect of store evaluative criteria, each item was analyzed independently rather than be developed into a composite scale.

\section{Results}

\section{Demographic Characteristics}

First data were analyzed to examine differences in the 
demographic characteristics in relation to market mavenism and fashion leadership. <Table 2>-<Table 4> summarize the results of multivariate and correlation analyses which were used to determine the relationships.

The relationship between demographic characteristics and fashion leadership was similar to the relationship between demographic characteristics with market mavenism with the exception of age. There were significant differences among males and females for both fashion leadership and market mavenism with females showing significant higher levels. In terms of ethnic group differences, although African American showed higher mean scores for both fashion leadership and market mavenism, post hoc tests showed no significant difference across ethnic groups for either variable. In terms of education, there was a significant difference between respondents with less than a high school degree and graduate degrees for both fashion leadership and market mavenism. Less educated respondents showed significantly higher tendencies for fashion leadership and market mavenism. In terms of age, there was a significant negative correlation between fashion leadership and age. No significant findings were present for income.

\section{Store Evaluative Criteria}

First, store evaluative criteria were studied in relation to fashion leadership, market mavenism, and gender using correlation analysis. As past studies have shown a difference among male and female consumers concerning their preferences for store characteristics, gender was initially examined to explain possible interaction effects. However, subsequent multivariate analyses confirmed no interaction effects to exist when examining the effects of fashion leadership and market maven groups with gender.

Correlation analysis <Table 5> showed a significant relationship with a high majority of store evaluative criteria items with both fashion leadership and market mavenism. Items related to store merchandise selection, prestige and recognition, and quality were all items that correlated significantly with market mavenism and fashion leadership. Two items, "The store offers good value/prices", and "The store is nearby or easily accessible" was not positively related

Table 2. Multivariate analysis of fashion leadership and market mavenism by gender

\begin{tabular}{c|c|c|c|c|c|c}
\hline \hline \multirow{2}{*}{} & Male & Female & \multicolumn{2}{c}{ Test of Between Subject Effects (df=1) } \\
\cline { 2 - 7 } & \multicolumn{2}{|c|}{ Mean } & Mean Square & F & Tukey HSD \\
\hline Fashion Leadership & 2.087 & 2.671 & 26.212 & 33.226 & Not applicable \\
\hline Market Mavenism & 2.738 & 3.191 & 15.801 & 19.128 & Not applicable \\
\hline
\end{tabular}

Wilks' Lamda $=.915, \mathrm{~F}=17.517, \mathrm{df}=2$

Table 3. Multivariate analysis of fashion leadership and market mavenism by education

\begin{tabular}{|c|c|c|c|c|c|c|c|}
\hline & $\begin{array}{c}1 \\
<\text { High }\end{array}$ & $\begin{array}{c}2 \\
\text { High }\end{array}$ & $\begin{array}{c}3 \\
\text { College }\end{array}$ & $\begin{array}{c}4 \\
\text { Graduate }\end{array}$ & \multicolumn{3}{|c|}{ Test of Between Subject Effects $(\mathrm{df}=3)$} \\
\hline & \multicolumn{4}{|c|}{ Mean } & Mean Square & $\mathrm{F}$ & Tukey HSD \\
\hline Fashion Leadership & 2.963 & 2.610 & 2.438 & 2.270 & 2.828 & 3.374 & 1 vs. 4 \\
\hline Market Mavenism & 3.454 & 3.212 & 2.989 & 2.717 & 4.769 & 5.735 & 1 vs. 4 \\
\hline
\end{tabular}

Wilks' Lamda $=.952, \mathrm{~F}=3.070, \mathrm{df}=6$

Table 4. Correlation analysis of fashion leadership and market mavenism by age and income

\begin{tabular}{c|c|c|c}
\hline \hline \multicolumn{2}{|c|}{} & Age & Income \\
\hline Fashion Leadership & Pearson Correlation & -0.242 & -0.029 \\
\hline & Sig. (2-tailed) & 0.000 & 0.579 \\
\hline Market Mavenism & Pearson Correlation & -0.090 & 0.001 \\
\hline
\end{tabular}


Table 5. Correlation analysis of store evaluative criteria with market mavenism and fashion leadership

\begin{tabular}{|c|c|c|c|}
\hline Store Evaluative Criteria & Fashion Leadership & Market Mavenism & Gender $^{\mathrm{b}}$ \\
\hline 1. The store offers good value/prices & 0.006 & 0.072 & $0.113^{*}$ \\
\hline 2. The store has a wide selection & $0.122 *^{\mathrm{a}}$ & $0.215 * *$ & $0.107^{*}$ \\
\hline 3. It is easy to return merchandise at the store & $0.161 * *$ & $0.180 * *$ & $0.146 * *$ \\
\hline 4. The salespeople have knowledge of the merchandise & 0.064 & $0.118^{*}$ & 0.060 \\
\hline 5. The store has a good reputation & $0.177 * *$ & $0.230 * *$ & $0.160 * *$ \\
\hline 6. The salespeople are friendly & $0.106^{*}$ & $0.112 *$ & 0.068 \\
\hline 7. The salespeople are helpful & 0.047 & $0.108 *$ & 0.019 \\
\hline 8. The store stocks well-known brands & $0.151 * *$ & $0.246 * *$ & 0.029 \\
\hline 9. The store stocks latest items & $0.373 * *$ & $0.351 * *$ & $0.114 *$ \\
\hline 10. The store is nearby or easily accessible & 0.004 & 0.013 & 0.070 \\
\hline 11. The store has a prestigious reputation & $0.262 * *$ & $0.217 * *$ & 0.049 \\
\hline 12. The store is well-liked by people I know & $0.248 * *$ & $0.303 * *$ & 0.056 \\
\hline 13. The store stocks upscale brands & $0.355 * *$ & $0.314 * *$ & $0.115^{*}$ \\
\hline 14. I can get what I want quickly at the store & $-0.110^{*}$ & $-0.110^{*}$ & $-0.134 * *$ \\
\hline 15. The store stocks products of good quality & $0.133 * *$ & $0.170 * *$ & 0.084 \\
\hline
\end{tabular}

Note: ${ }^{a} * *$ Correlation is significant at the 0.01 level (2-tailed). *Correlation is significant at the 0.05 level (2-tailed).

${ }^{\mathrm{b}}$ Gender variable coding: Male $=1$, Female $=2$

to either fashion leadership or market mavenism. On the other hand, there was a significant negative correlation for "I can get what I want quickly at the store" for both fashion leadership and market mavenism. In contrast to market mavenism, there were no signification relationships for fashion leadership for the following two items: "The salespeople have knowledge of the merchandise" and "The salespeople were helpful."

Next multivariate analysis was conducted to examine differences in store evaluative criteria for respondents that scored high in fashion leadership and market mavenism (Table 6)-(Table 7). Respondents in the fashion leaders group expressed significantly higher preferences for six of the 15 store evaluative criteria items ("It is easy to return merchandise at the store", "The store has a good reputation", "The store stocks well-known brands", "The store has a prestigious reputation", "The store is well-liked by people I know", and "The store stocks upscale brands"). On the contrary respondents in the fashion leader group scored significantly lower preferences for one item "I can get what I want quickly at the store". For respondents in the market maven group, respondents expressed significantly higher preferences for nine of the 15 items. These items included six items mentioned prior for fashion leaders and an additional three items ("The store has a wide selection", "The store stocks latest items", and "The store stocks products of good quality").

\section{Discussion and Limitations}

By comparing the characteristics and store preferences of consumers in relation to market mavenism and fashion leadership, this study furthers our understanding of fashion consumers at several levels. First, in terms of demographic characteristics, many similarities were found between fashion leaders and market mavens. Female consumers were found to be more active in word-of-mouth activities in general. In contrast, age was not related to market mavenism; consumers' overall consumption experience defined by years did not make individuals more prone to market mavenism. On the other hand, young consumers were more inclined to express fashion leadership supporting a strong majority of studies that confirm young female consumers to be more likely 
Table 6. Multivariate analysis of fashion leadership by store evaluative criteria

\begin{tabular}{l|r|r|r|r|r|c}
\hline \multirow{2}{*}{\multicolumn{1}{c|}{ Store Evaluative Criteria }} & $\begin{array}{c}\text { Non } \\
\text { Fashion } \\
\text { Leaders }\end{array}$ & $\begin{array}{c}\text { Moderate } \\
\text { Fashion } \\
\text { Leaders }\end{array}$ & $\begin{array}{c}\text { Fashion } \\
\text { Leaders }\end{array}$ & \multicolumn{2}{c}{ Test of Between Subject Effects } \\
(df=3)
\end{tabular}

Wilks' Lamda=.749, F=3.616, df=30

Table 7. Multivariate analysis of market mavenism by store evaluative criteria

\begin{tabular}{|c|c|c|c|c|c|c|}
\hline \multirow{2}{*}{ Store Evaluative Criteria } & $\begin{array}{c}\text { Non } \\
\text { Market } \\
\text { Mavens }\end{array}$ & $\begin{array}{c}\text { Moderate } \\
\text { Market } \\
\text { Mavens }\end{array}$ & $\begin{array}{l}\text { Market } \\
\text { Mavens }\end{array}$ & \multicolumn{3}{|c|}{$\begin{array}{l}\text { Test of Between Subject Effects } \\
\qquad(\mathrm{df}=2)\end{array}$} \\
\hline & \multicolumn{3}{|c|}{ Mean } & $\begin{array}{l}\text { Mean } \\
\text { Square }\end{array}$ & $\mathrm{F}$ & $\begin{array}{l}\text { Tukey } \\
\text { HSD }\end{array}$ \\
\hline 1. The store offers good value/prices & 4.32 & 4.29 & 4.42 & .646 & 1.586 & Not sig. \\
\hline 2. The store has a wide selection & 4.05 & 4.13 & 4.38 & 3.871 & 8.204 & 1,2 vs. 3 \\
\hline 3. It is easy to return merchandise at the store & 3.89 & 4.08 & 4.23 & 3.625 & 4.141 & 1 vs. 3 \\
\hline 4. The salespeople have knowledge of the merchandise & 4.07 & 4.21 & 4.25 & 1.115 & 1.562 & Not sig. \\
\hline 5. The store has a good reputation & 3.82 & 4.06 & 4.30 & 7.493 & 10.576 & 1 vs. 3 \\
\hline 6. The salespeople are friendly & 4.12 & 4.21 & 4.32 & 1.393 & 2.422 & Not sig. \\
\hline 7. The salespeople are helpful & 4.23 & 4.31 & 4.38 & .762 & 1.337 & Not sig. \\
\hline 8. The store stocks well-known brands & 3.52 & 3.85 & 3.99 & 7.200 & 9.099 & 1 vs. 2.3 \\
\hline 9. The store stocks latest items & 3.08 & 3.52 & 3.90 & 21.628 & 24.537 & 1 vs. 2 vs. 3 \\
\hline 10. The store is nearby or easily accessible & 3.99 & 3.87 & 4.01 & .673 & .866 & Not sig. \\
\hline 11. The store has a prestigious reputation & 2.54 & 3.07 & 3.19 & 14.908 & 11.765 & 1 vs. 2.3 \\
\hline 12. The store is well-liked by people I know & 2.41 & 2.91 & 3.09 & 15.618 & 12.464 & 1 vs. 2.3 \\
\hline 13. The store stocks upscale brands & 2.42 & 2.81 & 3.29 & 24.680 & 19.632 & 1 vs. 2 vs. 3 \\
\hline 14. I can get what I want quickly at the store & 4.13 & 3.94 & 3.96 & 1.231 & 1.497 & Not sig. \\
\hline 15. The store stocks products of good quality & 4.31 & 4.42 & 4.58 & 2.485 & 6.284 & 1 vs. 3 \\
\hline
\end{tabular}

Wilks' Lamda $=.756, \mathrm{~F}=3.498, \mathrm{df}=30$ 
interested in fashion. An interesting finding is that a lower level of education increased tendencies for market mavenism and fashion leadership. An interesting study for future inquiry might examine whether highly educated consumers engage in more independent information search strategies rather than collaborative decision making due to such factors as self confidence in decision-making. This study also finds that fashion leadership and market mavenism exist at all economic income levels providing evidence that one's consumption power has no effect on tendencies of fashion leadership and market mavenism. The single demographic characteristic differentiating fashion leadership and market mavenism was age. With this finding, we are able to conclude that fashion is indeed a consumption domain of younger consumers.

In terms of store evaluative criteria, the majority of items in the survey were more important as fashion leadership and market mavenism tendencies increased. However, the current study finds that consumers who had higher tendencies for both fashion leadership and market mavenism did not perceive a store's value/ prices and accessibility to be more important providing evidence that consumers with word-of-mouth tendencies are not necessarily bargain hunters and do not consider convenience in shopping as a major factor. Interestingly, a major difference in store evaluative criteria was that the need for knowledgeable or helpful salespeople did not increase with fashion leadership tendencies whereas a positive relationship in regards to market mavenism was found. When examining consumer groups based on the trichotomization method, the differences in the store evaluative criteria of market mavens versus non mavens mirrored those of fashion leaders versus non fashion leaders with a few exceptions. When examining consumer groups categorized into fashion leaders versus non-fashion leaders and market mavens versus nonmarket mavens, we can see that the consumer group categorized as fashion leaders and market mavens put more emphasis on the reputation, prestige, and likeability of the store. Also, fashion leaders were interested in easy return of merchandise and were likely to spend more time in the stores.

The two statistical procedures used to study the differences in the general store evaluative criteria of fashion leaders and market mavens show how the shopping behavior of fashion leaders are unique compared to market mavens. These results provide implications for marketing and retailing to individuals with fashion leadership tendencies and more importantly marketing and retailing fashion products in stores. First, it appears that because individuals with higher levels of fashion leadership are more independent consumers, fashion leaders may more likely gather information about various products independently from other types of information sources such as magazines, media, etc. Also, the importance of easy return of merchandise among consumers with higher levels of fashion leadership provide evidence of higher levels of experimental decision making and lower sense of risk in making a purchase. Another important aspect of fashion leaders was their willingness to spend more time at the store, which may explain for their less need for quicker decision making. Our results show that consumers with fashion leadership tendencies share many similarities with market mavens in how they evaluate stores, however, this study also highlights the uniqueness of how fashion leaders evaluate stores differently.

This study sheds important light on how fashion leadership differs compared to market mavenism. Age is a significant demographic characteristic that differentiates the two word-of-mouth market agents. In addition, we find that preferences related to customer service and breadth and quality of assortment offerings also differentiate fashion leaders and market mavens. By simultaneously examining fashion leadership and market mavenism using a strong sample base, this study provides sound evidence of how consumers interested in fashion may have differing needs for shopping. We nonetheless note the limitations of the study. First, as mentioned above, the data from this study were generated from a national survey in the United States, further studies on other regions of the world is recommended in order for the current findings to be generalized to other regions of the world. Next, store evaluative criteria items were selected to measure consumers' general shopping tendencies and not specific to any product category. 
Other measures that specifically focus on shopping behavior in terms of fashion might be studied in future studies. In addition, our measures for store evaluative criteria do not include store attributes that relate to mood or entertainment. These hedonic dimensions that influence shopping could be investigated in future studies.

\section{References}

Abratt, R., Nel, D., \& Nezer, C. (1995). Role of the market maven in retailing: A general marketplace influencer. Journal of Business and Psychology, 10(1), 31-56.

Bettman, J. R., \& Sujan, M. (1987). Effects of framing on evaluation of comparable and noncomparable alternatives by expert and novice consumers. Journal of Consumer Research, 14(2), 141-154.

Dickson, P. R. (1982). Person-situation: Segmentation's missing link. Journal of Marketing, 46(3), 56-64.

Fairhurst, A. E., Good, L. K., \& Gentry, J. W. (1989). Fashion involvement: An instrument validation procedure. Clothing and Textiles Research Journal, 7(3), 10-14.

Feick, L. F., \& Price, L. L. (1987). The market maven: A diffuser of marketplace information. Journal of Marketing, 51(1), 83-97.

Goldsmith, R. E., Heitmeyer, J. R., \& Frieden, J. B. (1991). Social values and fashion leadership. Clothing and Textiles Research Journal, 10(1), 37-45.

Goldsmith, R. E., Stith, M. T., \& White, J. D. (1987). Race and sex differences in self-identified innovativeness and opinion leadership. Journal of Retailing, 63(4), 411-425.

Gutman, J., \& Mills, M. K. (1982). Fashion life style, selfconcept, shopping orientation, and store patronage: An integrative analysis. Journal of Retailing, 58(2), 64-86.

Higie, R. A., Price, L. L., \& Feick, L. F. (1987). Types and amount of word-of-mouth communication about retailers. Journal of Retailing, 63(3), 260-278.

Hirschman, E. C. (1979). Intratype competition among department stores. Journal of Retailing, 55(1), 20-34.

Hirschman, E., \& Adcock, W. (1977). An examination of innovative communicators, opinion leaders and innovators for men's fashion apparel. Advances in Consumer Research, 5, 308-314.

Huddleston, P., Ford, I., \& Bickle, I. (1993). Demographic and lifestyle characteristics as predictors of fashion opinion leadership among mature consumers. Clothing and Textiles Research Journal, 11(4), 26-31.

Kaiser, S. (1985). The social psychology of clothing and personal adornment. New York: Macmillan.

Lichtenstein, D. R., \& Burton, S. (1990). An assessment of the moderating effects of market mavenism and value consciousness on price-quality perception accuracy. Advances in Consumer Research, 17, 53-59.

Nunnally, J. C. (1978). Psychometric theory (2nd ed.). New York: McGraw-Hill.

Polegato, R., \& Wall, M. (1980). Information seeking by fashion opinion leaders and followers. Home Economics Research Journal, 8, 327-338.

Price, L. L., Feick, L. F., \& Higie, R. A. (1987). Information sensitive consumers and market information. Journal of Consumer Affairs, 21(2), 328-341.

Rogers, E. M. (1983). Diffusion of innovation (3rd ed.). New York: The Free Press.

Slama, M. E., \& Williams, T. G. (1990). Generalization of the market maven's information provision tendency across product categories. Advances in Consumer Research, 15, 354-349.

Summers, J. O. (1970). Identity of women's clothing fashion opinion leaders. Journal of Market Research, 7, 178-185.

Summers, T. A., Belleau, B. D., \& Wozniak, P. J. (1992). Fashion and shopping perceptions, demographics, and store patronage. Clothing and Textiles Research Journal, 11(1), 83-92.

Tatzel, M. (1982). Skill and motivation in clothes shopping: Fashion-conscious, independent, anxious, and apathetic consumers. Journal of Retailing, 58, 90-97.

Walsh, G., \& Mitchell, V. W. (2001). German market mavens' decision-making styles. Journal of Euromarketing, 10(4), 83-108.

Walsh, G., Gwinner, K. P., \& Swanson, S. R. (2004). What makes mavens tick? Exploring the motives of market mavens' initiation of information diffusion. Journal of Consumer Marketing, 21(2), 109-122.

Wiedmann, K.-P., Walsh, G., \& Mitchell. V.-W. (2001). The Mannmaven: An agent for diffusing market information. Journal of Marketing Communications, 7(4), 195212.

Williams, T. G. (2002). Social class influence on purchase evaluation criteria. Journal of Consumer Marketing, 19(3), 249-276.

Williams, T. G., \& Slama, M. E. (1995). Market mavens' purchase evaluative criteria: Implications for brand and store promotion efforts. Journal of Consumer Marketing, 12(3), 4-21. 


\section{요 약}

본 연구에서는 소비자들의 인구통계적 특징별로 패션선도력과 시장전문성 수준을 비교하고, 패션선도 력과 시장전문성 수준에 따라 점포평가기준에 차이가 있는지를 알아보고자 하였다. 미국 전역의 소비자 를 대상으로 우편설문조사를 실시하여 380 부의 설문자료를 분석에 사용하였다. 결과에서 인구통계적 특 성별로 패션선도력과 시장전문성 수준이 대체로 유사하게 나타났다. 여성 소비자들은 일반적으로 패션선 도력과 시장전문성이 남성보다 더 강하며 교육수준이 낮을수록 시장전문성과 패션선도력이 높은 것으로 나타났다. 연령이 낮을수록 패션선도력은 더 강한 것으로 나타났으나 시장전문성에서는 연령별 차이가 발견되지 않았다. 패션선도력이 높고 시장전문성이 강할수록 더 많은 점포속성들을 더 중요한 평가기준 으로 고려하는 것으로 확인되었다. 특히 시장전문성이 강한 소비자들은 그렇지 않은 소비자들에 비해 상 품의 품질이 우수한지, 환불교환이 용이한지, 더 넓은 상품구색이 갖추어져 있는지를 더 중요하게 고려하 였으며, 패션선도력이 강한 소비자들은 그렇지 않은 소비자들에 비해 환불용이성과 점포명성 등을 더 중 요한 점포평가기준으로 고려하는 것으로 나타났다. 